\title{
Oral Manifestations of Systemic Lupus Erythematous and Its Comprehensive Management: Two Case Reports
}

\author{
Rita Wardhani, Irna Sufiawati \\ Department of Oral Medicine Faculty of Dentistry Universitas Padjadjaran Bandung, Indonesia
}

\begin{abstract}
Abstrak
Systemic lupus erythematous (SLE) is an autoimmune collagen-vascular disease involving mucocutaneous and musculoskeletal systems as well as blood vessels that is characterized by diverse clinical manifestations, making it necessary to use a comprehensive multidisciplinary approach. Oral manifestations of SLE include oral ulcer, discoid lesions, oral lichen planus-like-lesion, oral candidiasis, and xerostomia. This study reports two cases of 19-year-old and 41-year-old female patients visiting the Oral Medicine Department Dr. Hasan Sadikin General Hospital in October 2016. These patients were referred by the Internal Medicine Department with SLE diagnosis, involving hematological, musculoskeletal and mucocutaneous systems. Extraoral examination revealed moon face in the first patient and malar rash and lips exfoliations in the second patient. Intraoral examination revealed oral ulcers on buccal and labial mucosa as well palate in both patients. Both patients were given methyl prednisolone, calcium, and folic acid by the Internal Medicine Department. Oral ulcers were treated with prednisone mouthwash, nystatin oral suspension, and vitamin B12. The oral ulcer on palate was considered very difficult to resolve so that topical corticosteroid was required. Prednisone mouthwash was chosen as drug of choice due to its efficacy on oral mucosa and its ability to minimize the systemic adverse effects which were resolved in 6 week after starting treatment. Comprehensive multidisciplinary approach associated with oral manifestation of SLE has significant effects in decreasing disease severity and improving the quality of life in patients with SLE.
\end{abstract}

Key words: Oral ulcers, prednisone mouthwash, systemic lupus erythematosus

\section{Manifestasi Oral Lupus Eritematosus Sistemik dan Manajemen Komprehensifnya: Dua Laporan Kasus}

\begin{abstract}
Abstrak
Sistemik lupus eritematosus (SLE) adalah penyakit kolagen-vaskular autoimun, yang melibatkan sistem mukokutan, muskuloskeletal, dan pembuluh darah yang ditandai dengan manifestasi klinis yang bervariasi, sehingga diperlukan pendekatan multidisiplin yang komprehensif. Manifestasi oral SLE meliputi ulkus mulut lesi diskoid, lichen planus-like lesion, kandidiasis oral, dan serostomia. Pasien wanita berusia 19 tahun dan 41 tahun yang dirujuk dari departemen Penyakit Dalam pada Oktober 2016 dengan diagnosis SLE yang melibatkan hematologis, muskuloskeletal, dan mukokutan. Pemeriksaan ekstraoral menunjukkan moon face pada pasien pertama, dan malar rash serta pengelupasan bibir pada pasien kedua. Pemeriksaan intra oral mengungkapkan ulkus oral, mukosa labial, dan palatum pada kedua pasien. Kedua pasien diberikan metil prednisolone, kalsium, dan asam folat dari departemen Penyakit Dalam. Ulkus oral diobati dengan obat kumur prednison, suspensi oral Nistatin, dan vitamin B12 yang diberikan dalam 6 minggu pengobatan. Ulkus oral adalah salah satu manifestasi oral yang umum pada pasien SLE. Ulkus oral pada palatum dianggap sangat sulit diatasi sehingga dibutuhkan kortikosteroid topikal. Prednisone mouth wash dipilih sebagai obat pilihan sebagai anti-inflamasi pada mukosa oral dan meminimalkan efek samping sistemik. Pendekatan multidisiplin komprehensif yang terkait dengan manifestasi oral SLE memiliki efek signifikan dalam menurunkan tingkat keparahan penyakit dan meningkatkan kualitas hidup pada pasien SLE.
\end{abstract}

Kata kunci: Lupus eritematosus sistemik, ulser oral, obat kumur prednison

Correspondence: Rita Wardhani, drg. Department of Oral Medicine Faculty of Dentistry Universitas Padjadjaran, Jalan Sekeloa Selatan No.1 Bandung, West Java, E-mail: drgritawardhani@gmail.com, irna.sufiawati@fkg.unpad.ac.id 


\section{Introduction}

A wide spectrum of oral mucosal lesions is found in cutaneous and systemic forms of lupus erythematosus (LE): cheilitis, erythematous patches, honeycomb plaques, discoid lesions, lichen planus (LP)-like lesions and discrete ulcers have been described. In establishing disease, reported prevalence rates range from $9 \%$ to $45 \%$ of cases, although the true figure may be nearer to $20 \%$. The frequency with which systemic LE (SLE) presents with oral mucosal lesions remains uncertain as there are only a few cases reported in the literature..$^{1-3}$

Systemic lupus erythematosus (SLE) is a prototypic autoimmune disease characterised by the production of antibodies to components of the cell nucleus in association with a diverse array of clinical manifestations. The primary pathological findings in patients with SLE are those of inflammation, vasculitis, immune complex deposition, and vasculopathy. The exact aetiology of SLE is unknown. SLE shows a strong familial aggregation, with a much higher frequenc yamongfirstdegreerelativesofpatients. Moreover, in extended families, SLE may coexist with other organ specific autoimmune diseases such as haemolytic anaemia, immune thrombocytopenic purpura, and thyroiditis. The concord-ance of the disease in identical twins is approximately $25-50 \%$ and that in dizygotic twins is around 5\%. This suggests that genetic factors playanimportantroleinthepredispositionofthe disease. However, most cases of SLE are sporadic without identifiable genetic predisposing factors, suggesting that multiple environmental or yet unknown factors may also be responsible., ${ }^{2,45}$

Prevalence rates in lupus are estimated to be as high as 51 per 100000 people in the USA. Th e incidence of lupus has nearly tripled in the last 40 years, mainly due to improved diagnosis of mild disease. Estimated incidence rates in North America, South America, and Europe range from 2 to 8 per 100000 per year. Women are affected nine times more frequently than men and African American and Latin American mestizos are aff ected much more frequently than Caucasians, and have higher disease morbidity. Th e disease appears to be more common in urban than rural areas. Sixty-five per cent of patients with SLE have disease onset between the ages of 16 and 55 years, $20 \%$ present before age 16, and 15\% after the age of 55. Men with lupus tend to have less photosensitivity, more serositis, an older age at diagnosis, and a higher 1 year mortality compared to women. SLE tends to be milder in the elderly with lower incidence of malar rash, photosensitivity, purpura, alopecia, Raynaud's phenomenon, renal and central nervous system involvement, but greater prevalence of serositis, pulmonary involvement, sicca symptoms, and musculoskeletal manifestations. ${ }^{1-3}$

Different studies of oral lesions in the course of LE have shown a frequency varying from $9 \%$ to $45 \%$ in systemic disease and $3 \%$ to $20 \%$ in localized cutaneous disease. Our group reported 26 patients with oral lesions among 188 LE patients studied, 13 of these had SLE according to the ACR criteria. Nineteen patients were female and 7 were male. Burge et al. reported 10 female and 4 male patients with oral lesions of LE, of these, 5 were considered to have SLE and 9 had localized cutaneous LE. In a further study by our group, oral lesions were diagnosed in 46 patients, only 13 had SLE according to established criteria. A possible reason for the lower frequency of oral lesions when compared with skin lesions may be the lack of ultraviolet radiation incidence in the oral cavity in contrast to the skin. ${ }^{1,6,7}$

Oral lesions occurring during the course of lupus erythematosus (LE) have long been described in dermatological, rheumatological and dental literature. Many attempts have been made to correlate these manifestations with the prognosis of systemic LE (SLE) (oral ulcerations are included among the American College of Rheumatology criteria for systemic LE, but conclusions vary. Reproducible criteria in the classification of oral lesions in LE are lacking and as a consequence, comparison between existing studies is hampered. ${ }^{3,6,8}$

\section{Case Reports}

In these case, we report two case of 19-yearold and 41-year-old female patients which was referred from Internal Medicine Department to Oral Medicine Department of Dr Hasan Sadikin Hospital Bandung in October 2016. Patient with SLE diagnosis, involving hematological, musculoskeletal and mucocutaneous. Extraoral examination revealed moon face in the first patient, and malar rash and lips exfoliations in second patient. Intra oral examination revealed oral ulcers on buccal, labial mucosa, and palate in both patients. Both patients were given by internal medicine methyl prednisolone since the patient diagnosed by SLE until now, calcium, and folic acid for a month. We gave prednisone $5 \mathrm{mg}$ in $10 \mathrm{~mL}$ aquadest as mouthwash three times a 

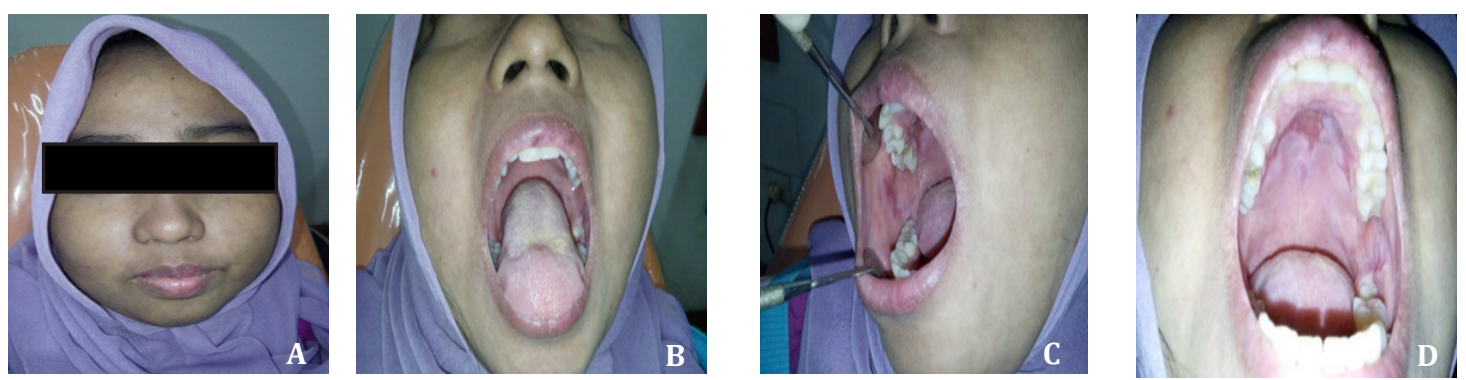

Figure 1 Clinical Features in 19 Years Old Patient at First Visite

A. moon face; B. coated tongue; C. oral ulcers at right buccal mucous; D. hard palate

day, nystatin oral suspension four time $1 \mathrm{ml} \mathrm{a}$ day, and vitamin $B_{12} 50$ mcg 2 times a day, all the prescribe for a week.

Clinical descriptions of oral LE lesions vary enormously in the different studies. Terms used include: oral discoid lesion, chronic plaque, lupus cheilitis, red ulcer, ulcerative plaques, pebbly red areas, honeycomb lesion, keratotic lesion, white keratotic plaques, purpuric lesions and diffuse palatal petechial erythema. Thus, in contrast to cutaneous LE, no uniformity exists in classifying oral LE lesions, and an adequate clinical categorization is lacking. Additionally and yet more confusing,oral ulcerations in LE patients have for a long time been considered as a sign of vasculitis and predictors of severe systemic flares of the disease. ${ }^{6,9,10}$

In the Figure 1 explain the examination of the first patient, we find the moon face, coated tongue, oral ulcer at bucal mucous and hard palate. Treatment from Oral Medicine Department is prednison mouthrinse $5 \mathrm{mg}$, three times a day for a week, vitamin $B_{12}$ and folic acid for 6 weeks.

In Figure 2 we can see the malar rash, coated tongue, oral ulcers at buccal mucous and hard palate in the second patient. Treatment of oral medicine is prednison $5 \mathrm{mg}$ mouthrinse three times a day for a week, dexametason zalp three times a day, vitamin $B_{12} 50$ mcg two times a day and folic acid $1 \mathrm{mg}$ once a day for a week.

The malar edematous butterfly lesion was appeared on the face of the patient figure $2 \mathrm{~A}$, a corresponding wide spread eruption and bullous LE. These presentations almost always indicate systemic LE, with its diagnostic serological changes and manifestations in other organs. The result of ANA test was shows positive. These cutaneous lesions tend to heal without scarring since inflammatory component is scarce. Oral lesions in the setting of systemically ill LE patient sarevery common. There are many possible clinical presentations: circumscribed red macules, diffuse or palatal erythema, purpuric macules, and erosions or ulcerations that mayor may not be symmetrically distributed in the mucosa. These can occasionally be present in the absence of skin lesions. ${ }^{2,4,11}$

\section{Results}

The result of this case report in the first patient still had moon face, tongue more clean than before, the ulcer at the buccal mucous still there and healing of oral ulcer at hard palate after 6 weeks therapy from oral medicine department. The second patient still malar rash, the clean tongue, and resolved of oral ulcer at buccal
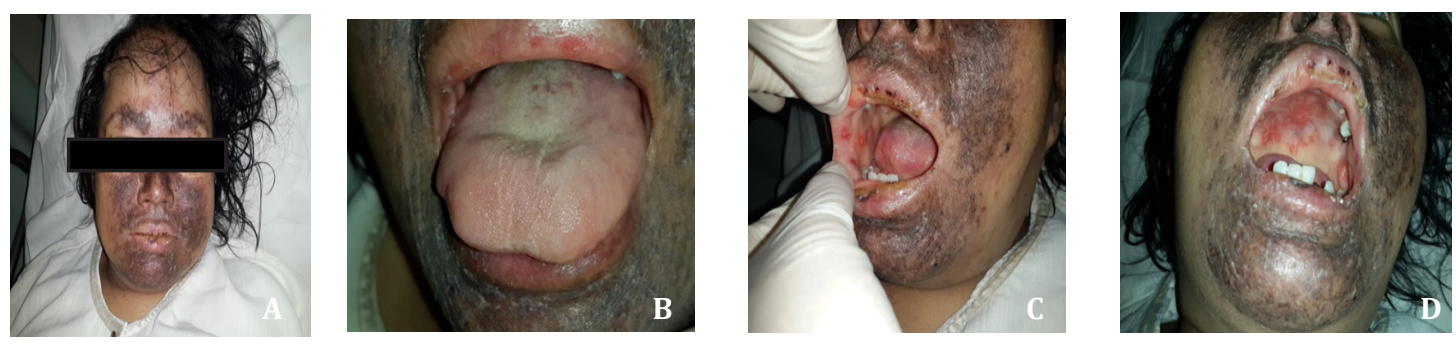

Figure 2. Clinical Features in 41 Years old Patient

A. moon face; B. coated tongue; C. oral ulcers at right buccal mucous; D. hard palate 

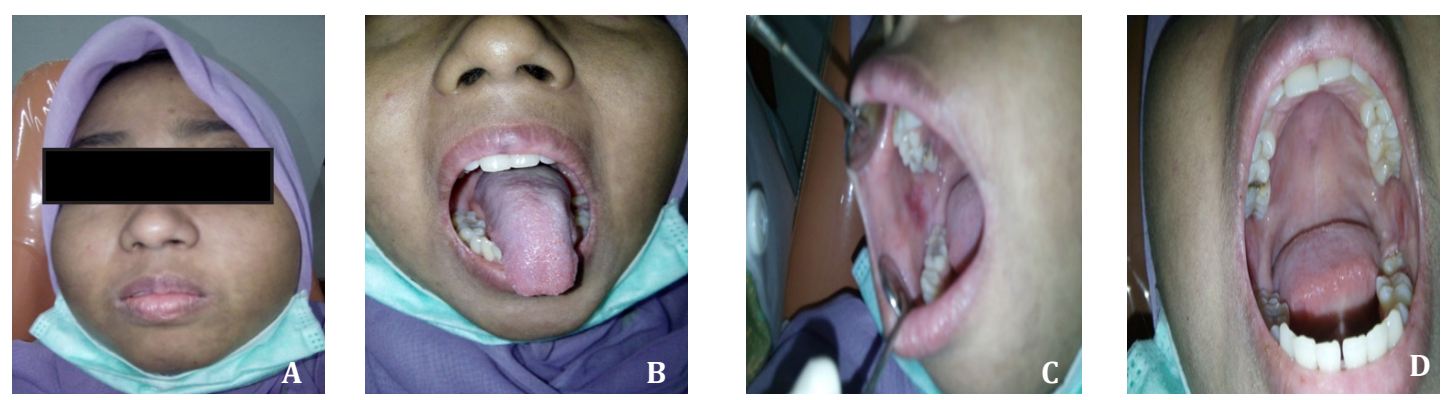

Figure 3 Clinical Feature in Last Visite

A. moon face; B. tongue; C. ulcer at right buccal mucous; D. healing at hard palate

mucous and hard palate after 6 weeks therapy. At the first visit extra oral examination revealed clinical sign of moon face cause her steroid treatment for long time, tongue more clean than before, the ulcer at the buccal mucous still there and healing of oral ulcer at hard palate after 6 weeks therapy, and must be evaluation in next month.

In Figure 4 from second patient still malar rash, the clean tongue, and resolved of oral ulcer at buccal mucous and hard palate after 6 weeks therapy.

\section{Discussions}

We have reported two patients who presented oral lesions that were diagnosed initially as LE, but who subsequently developed other features of SLE. Malar rash was appeared in the second patient but not in another patient. We found the same type of oral lesion in both of the patient which were oral ulcers on the buccal mucosal and hard palate. It is difficult to ascertain the true incidence with which SLE presents with oral involvement because of a relative lack of symptoms and different referral pathways. Oral mucosal lesions are frequently chronic, with a mean duration of 4 years for discoid lesions in one study, and may be asymptomatic in $50 \pm 80 \%$ of patients. Symptomatic patients may present early to dentists, oral surgeons or physicians, whereas asymptomatic patients may not present until much later, when they develop cutaneous or systemic manifestations. Of patients seen by dermatologists, $15 \pm 36 \%$ give a retrospective history of oral ulcers at the onset of their disease, but it is not known what proportion represent true lupus ulcers ${ }^{1,3,12}$

Oral ulcerations or ulcers in the setting of SLE have long been considered to be predictors of systemic vasculitis and worse prognosis. Jorizzo et al in 2014 roved that these lesions represent, in fact, specific lupus lesions clinically and histopathologically (interface mucositis), without prognostic implications. Curiously, though, the same group of authors, in a latter review, stated that these ulcers are non-specific manifestations of SLE heralding serious disease. However, no explanation is offered on their nature or histopathological findings. Established prognostic indexes for systemic LE in the rheumatological literature, such as the systemic lupus activity measure (SLAM), equivocally classify oral LE ulcers together with peri unguenal erythema, photosensitive rash and nail foldin farcts (mostly non specific LE lesions), and separated from erythematous
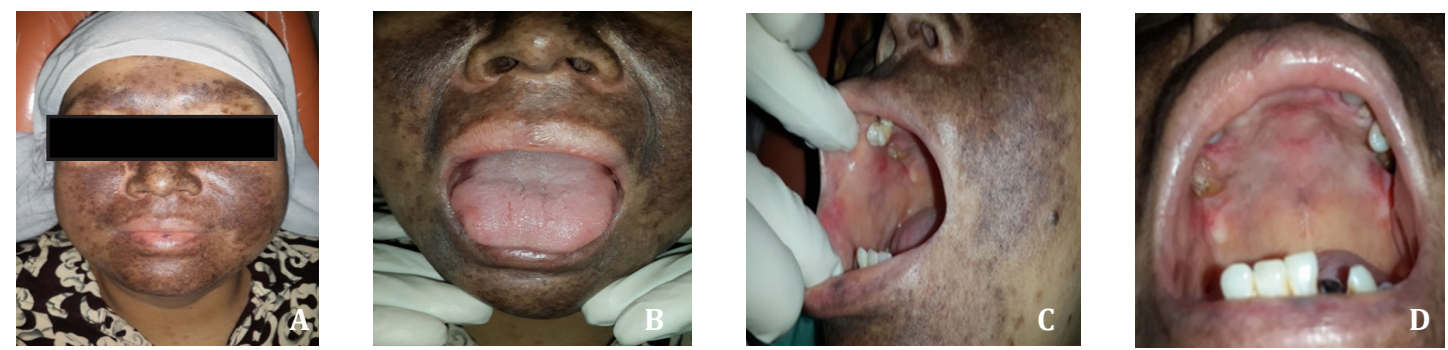

Figure 4 Clinical Features at the Last Visit in 41 years Old Patient

A. Malar rash; B. Dorsal tongue; C. resolved of oral ulcer at buccal mucous; D. hard palate 
rash, discoid lesions, lupus paniculitis, bullous lesions (specific LE lesions). This classification probably provides unnecessary additional value to mucocutaneous specific LE lesions in establishing systemic prognosis. ${ }^{4,6,13}$

The basic pathological features of SLE are that of inflammation and blood vessel abnormalities, which include band or occlusive vasculopathy, vasculitis, and immune complex deposition. The best characterised organ pathologyis in the kidney. By light and immunofluorescence microscopy, renal biopsies in patients with SLE display mesangial cell proliferation, inflammation, basement membrane abnormalities, and immune complex deposition, comprising immunoglobulins and complement components. On electron microscopy, these deposits can be visualised in the mesangium and the subendothelial or subepithelial surface of the basement membrane. Other organ systems affected by SLE usually display non specific inflammation or vascular abnormalities, although pathological findings are sometimes minimal. One example is cortical microin farcts and bland vasculopathy with degenerative or proliferative changes in patients with central nervous system disease. Inflammation and necrotising vasculitis can rarely be found. Occlusive vasculopathy is a common histological feature associated with the presence of anti phospholipid antibodies. Atherosclerosis and tissue damage caused by hypertension, corticosteroids, and other drugs can be demonstrated in patients with long standing SLE. ${ }^{2,14,15}$

Acute rashes malar rash. The classic lupus butterfly rash presents acutely as an erythematous, elevated lesion, pruritic or painful, in a malar distribution, commonly precipitated by exposure to sunlight. The rash may last from days to weeks and is commonly accompanied by other inflammatory manifestations of the disease. The acute butterfly rash should be differentiated from other causes of facial erythema such as rosacea, seborrhoeic, atopic, and contact dermatitis, and glucocorticoid-induced dermal atrophy and flushing. Other acute cutaneous lesions include generalised erythema and bullous lesions. The rash of acute cutaneous lupus erythematosus can be transient and heal without scarring, although persistently active rashes may result in permanent telangiectasias. ${ }^{6,10,13}$

Clinical differential diagnosis of LE mucositis will depend on the morphology of the lesion analyzed. The main differential diagnoses for keratotic discoid lesions are LP, lichenoid reactions to dental fillings, traumatic and smoker's keratoses, and verrucous carcinoma. Ulcerated discoid lesions should be differentiated from aphthae, erosive LP, traumatic ulcers, deep mycoses, Langerhans cells histiocytosis and SCC (SCC can develop in old scarring LE lesions). Lip lesions may simulate contact cheilitis, factitious cheilitis, actinic cheilitis, LP, psoriasis, erythema multiforme, pemphigus vulgaris and SCC. Erythematous or purpuric macules may resemble LP, erythema multiforme, mucous patches of syphilis, petechiae of viral exanthem, and negative pr essure purpura (fellatio syndrome). Finally, differential diagnoses for oral bullous LE include pemphigus vulgaris, mucous membrane pemphigoid, herpes simplex, varicella, and erythema multiforme with its variants (Stevens-Johnson disease and toxic epidermal necrolysis), ${ }^{2,6,16,19}$

Regarding methyl prednisolone pulses, Badsha and colleagues retrospectively evaluated 55 SLE patients who had received low-dose 1500 $\mathrm{mg}$ over three days) or high-dose intravenous methyl prednisolone pulses 11 gr per day for three days). They found equivalent effectiveness in controlling disease activity with significantly fewer infections in those who received the lowdose regimen (seven vs $20, \mathrm{p}<0.05$ ). $4,17,20$

Although current treatment of lupus has improved survival dramatically, prolonged and complete remission defined as 5 years without clinical and laboratory evidence of active disease and on no treatment has remained elusive for most patients. The incidence of flare is estimated to 0.65 per patient-year of followup. Moreover, a significant number of patients (10-20\% in tertiary referral centres) do not respond adequately to immunosuppressive therapies. ${ }^{2,14,18}$

In conclusion, comprehensive multidisciplinary approach associated with oral manifestations of SLE has significant effect in decreasing disease severity and improving the quality of life in patients with SLE.

\section{References}

1. Bertsias G, Carvera R, Boumpas TD. Systemic Lupus erythematosus: pathogenesis and clinical features. In: Bijlsma JWJ, editor. EULAR textbook on rheumatic diseases. $1^{\text {st }}$ Edition. London: BMJ Group; 2012. p. 476505.

2. Danza A, Ruiz-Irastorza G. Infection risk in systemic lupus erythematosus patients: susceptibility factors and preventive 
strategies. Lupus. 2013;22(12):1286-94.

3. Nico MM, Vilela MA, Rivitti EA, Lourenco SV. Oral lesions in lupus erythematosus: Correlation with cutaneous lesions. Eur J Dermatol. 2008;18(4):376-81.

4. Crispín JC, Liossis SN, Kis-toth K, Lieberman LA, Kyttaris VC, Juang Y, Tsokos GC. Pathogenesis of human systemic lupus erythematosus: recent advances. Trends Mol Med. 2010;16(2):47-57.

5. Handa R. Management of systemic lupus erythematosus. In: Rao MS, Editor. Medicine update. Volume 20. Mumbai: APIIndia; 2010. p. 839-44.

6. Hahn BH, McMahon MA, Wilkinson A, Wallace WD, Daikh DI, Fitzgerald JD, et al. American college of rheumatology guidelines for screening, treatment, and management of lupus nephritis. Arthritis Care Res (Hoboken). 2012;64(6):797-808.

7. de Araújo ALPK, Paliares IC, de Araújo MIPK, Novo NF, Cadaval RAM, Martinez JE. The association of fibromyalgia and systemic lupus erythematosus change the presentation and severity of both diseases?. Rev Bras Reumatol. 2015;55(1):37-42.

8. Chiewchengchol D, Murphy R, Edwards SW, Beresford MW. Mucocutaneous manifestations in juvenile-onset systemic lupus erythematosus: a review of literature. Pediatr Rheumatol Online J. 2015;13(1):1-9.

9. Pisetsky DS. Systemic lupus erythematosus B. Epidemiology, pathology, and pathogenesis. In: Klippel JH, Stone JH, Crofford LJ, White $\mathrm{PH}$, editors. Primer on the Rheumatic Diseases. $13^{\text {th }}$ Edition. New York: Springer; 2008. p. 319-27.

10. Zampeli E, Klinman DM, Gershwin ME, Moutsopoulos HM. A comprehensive evaluation for the treatment of lupus nephritis. J Autoimmun. 2017;78(1):1-10.
11. ShankarS, Behera V.Advances in management of systemic lupus erythematosus. Symp Rheumatol. 2014;19(1):28-36.

12. van Vollenhoven RF, Mosca M, Bertsias G, Isenberg D, Kuhn A, Lerstrøm K, et al. Treatto-target in systemic lupus erythematosus : recommendations from an international task force. Ann Rheum Dis. 2014;73(6):958-67.

13. Rahman A, Isenberg DA. Systemic lupus erythematosus. N Engl J Med. 2008;358(9): 929-39.

14. Braunwald E, Fauci AS, Kasper DL, Hauser SL, Longo DL, Jameson JL, editors. Harrisson's principle of internal medicine. $18^{\text {th }}$ Edition. USA: McGrawHill; 2012.

15. Sestak AL, Fürnrohr BG, Harley JB, Merrill JT, Namjou B. The genetics of systemic lupus erythematosus andimplications for targeted therapy. Ann Rheum Dis. 2011;70(1):i37-43.

16. Bosch X. Systemic lupus erythematosusand the neutrophil. N Engl J Med. 2011;365(8): 758-60.

17. Roy JS, Das PP, Datta A. SLE in pregnancy. BSMMU J. 2010;3(1):54-9.

18. Sanchez E, Nadig A, Richardson BC, Freedman BI, Kaufman KM, Kelly JA, et al. Phenotypic associations of genetic susceptibility loci in systemic lupus erythematosus. Ann Rheum Dis. 2011;70(10):1752-7.

19. Blank M, Shoenfeld Y, Perl A. Crosstalk of the environment with the host genome and the immune system through endogenous retroviruses insystemic lupus erythematosus. Lupus. 2009;18(13):113643.

20. Petri M, Orbai AM, Alarcón GS, Gordon C, Merrill JT, Fortin PR, et al. Derivation and validation of the systemic lupus international collaborating clinics classification criteria for systemic lupus erythematosus. Arthritis Rheum. 2012;64(8):2677-86. 